\title{
Enhancement of the release of inflammatory mediators by substance $P$ in rat basophilic leukemia RBL-2H3 cells
}

\author{
Ben-Ching Liao ${ }^{1}$, Rolis Chien-Wei Hou ${ }^{2}$, Jen-Shu Wang ${ }^{3,4}$ \& Kee-Ching G. Jeng ${ }^{1,5, *}$ \\ ${ }^{1}$ Institute of Biomedical Science, National Chung Hsing University, Taichung, ROC; ${ }^{2}$ Jen-Teh Junior College \\ of Medical and Nursing Management, Miaoli, Taiwan, ROC; ${ }^{3}$ Department of Chinese Medicine, China \\ Medical University, Taichung, ROC; ${ }^{4}$ Department of Chinese Medicine, Taichung Veterans General Hospital, \\ Taichung, Taiwan, ROC; ${ }^{5}$ Department of Education and Research, Taichung Veterans General Hospital, \\ Taichung, Taiwan, 40705, ROC
}

Received 27 April 2006; accepted 13 June 2006

(C) 2006 National Science Council, Taipei

Key words: allergen, ginsenoside $\mathrm{Rb}$, histamine, interleukin-4, leukotriene $\mathrm{C}_{4}$, mitogen-activated protein kinases, RBL-2H3 cells, substance $\mathrm{P}$

\begin{abstract}
Summary
Substance P (SP), a neurotransmitter, may play an important role in neurogenic inflammation. Ginseng has been used extensively in traditional medicine; however, few studies were focused on their anti-allergic effect. Therefore, the effect and mechanism of ginsenoside Rb1 on the SP enhancement of allergic mediators were explored. In this study, SP and dinitrophenyl-bovine serum albumin (DNP-BSA) were used to activate rat basophilic leukemia (RBL)-2H3 cells. The cultured supernatants were assayed for histamine, leukotriene $\mathrm{C}_{4}\left(\mathrm{LTC}_{4}\right)$ and interleulin-4 (IL-4) production. The mitogen-activated protein kinases (MAPKs) signaling pathway was determined by Western blotting analysis. We found that IgE/DNP-BSA, SP, ginsenoside Rb1, or MAPK specific inhibitors had no effect on cell viability and cytotoxicity. SP $(30 \mu \mathrm{M})$ alone, did not induce histamine and $\mathrm{LTC}_{4}$ release, but it enhanced allergen-induced histamine and $\mathrm{LTC}_{4}$ release. In addition, SP significantly induced and enhanced allergen-activated IL-4. Ginsenoside Rb1 dosedependently inhibited these effects. SP enhanced the allergen-activated ERK pathway in RBL-2H3 cells, and $\mathrm{Rb} 1$ effectively inhibited the ERK pathway activation. Although MAPK specific inhibitors suppressed LTC $_{4}$ and IL-4, only U0126 inhibited the SP enhanced histamine release. These results demonstrate that $\mathrm{Rb} 1$ dose-dependently inhibited SP enhanced allergen-induced mediator release and its mechanism was through the inhibition of the ERK pathway.
\end{abstract}

\section{Introduction}

Neurogenic inflammation is orchestrated by a large number of neuropeptides including tachykinins such as substance $\mathrm{P}(\mathrm{SP})$ and neurokinin $\mathrm{A}$, or calcitonin gene-related peptide $[1,2]$. SP and neurokinin $\mathrm{A}$, and its receptors are present in human and animal airways [1,3]. Local release of tachykinins affects blood vessels and broncho-

*To whom correspondence should be addressed. Fax +886-423592705, E-mail: kcjengmr@vghtc.gov.tw constrition and hyperresponsiveness. Tachykinins are important to mast cells, and they are chemotactic for neutrophils and eosinophils [1]. SP can stimulate histamine release from human mast cells of bronchoalveolar lavage and enhance anti-IgEinduced histamine release from rat peritoneal mast cells $[4,5]$.

SP and neurokinin A, act through neurokinin (NK)-1 and NK-2 receptors. NK-1 and NK-2 receptors are expressed in the lungs, and SP is released in the airways of rat sensitized to ovalbumin (OVA). The selective NK-1 or NK-2 
antagonists decreased OVA-induced late airway responses in challenged animals [6]. On the other hand, interleukin-4 (IL-4) and IgE-dependent mast cell activation play important roles in allergic airway inflammation [7, 8] and leukotriene (LT) induce contraction of the human airway smooth muscle, chemotaxis and increased vascular permeability [9-12]. These mediators play important roles in asthma and allergic rhinitis. SP induces LT- $\mathrm{B}_{4}$ and prostaglandin E2 in mice [13]. LTreceptor antagonist, montelukast is effective and safe in the treatment of patients with asthma and allergic rhinitis [9].

Ginsenoside Rb1 from Panax ginseng (Araliaceae) has a partial neurotrophic and neuroprotective role in dopaminergic cell cultures under glutamate stress [14]. Ginsenoside Rh2 and the metabolite of $\mathrm{Rb} 1$ have anti-inflammatory activities to LPS-induced macrophages $[15,16]$. Pretreatment with $\mathrm{Rb} 1$ significantly decreased histamine and LT in a dose-dependent manner during mast cell activation [17]. Rh2 had the most potent inhibitory activity on beta-hexosaminidase release from rat basophilic leukemia (RBL) cells and in the passive cutaneous anaphylaxis reaction [15]. However, the effects of SP and Rb1 on signaling pathway of mast cells have not been studied. Therefore, we were interested in studying the signaling pathway of SP enhancement on allergen-induced RBL-2H3 cells and the effect of $\mathrm{Rb} 1$ on this neurogenic inflammation model.

\section{Materials and methods}

Ginsenoside Rb1, anti-dinitrophenyl (DNP) IgE monoclonal antibody, substance $\mathrm{P}$ and $o$-phthalaldehyde were obtained from Sigma (St. Louis, MO, USA). Dinitrophenyl-bovine serum albumin (DNP-BSA) was obtained from Calbiochem (San Diego, CA, USA) and MAP kinase inhibitors, SB203580, SP600125, and U0126 were obtained from Biomol (Plymouth Meeting, PA, USA). Fetal calf serum (FCS) was obtained from BIOLOGICAL INDUSTRIES (Kibbutz Beit Haeme, Israel). Penicillin, streptomycin, and Dulbecco's Modified Eagle's medium (DMEM) were purchased from GIBCO (Grand Island, NY, USA). Mammalian protein extraction reagent (M-PER) was obtained from PIERCE (Rockford, IL, USA). Anti-phospho-p38, ERK, JNK, or $\beta$-actin antibodies were purchased from Abcam (Cambridge, UK).

\section{Cell culture and mediator assay}

The RBL-2H3 cell line was maintained in DMEM supplemented with $10 \%$ fetal bovine serum (FBS), $100 \mathrm{U} / \mathrm{ml}$ penicillin and $100 \mu \mathrm{g} / \mathrm{ml}$ streptomycin at $37{ }^{\circ} \mathrm{C}$ in a humidified incubator under $5 \% \mathrm{CO}_{2}$. Confluent cultures were passed by trypsinization. The RBL cells were seeded at $2 \times 10^{5}$ cells/well. and sensitized with $10 \mathrm{ng} / \mathrm{ml}$ of anti-DNP IgE for $1 \mathrm{~h}$ at $37{ }^{\circ} \mathrm{C}$. The cells were then washed with Hank's balanced salt solution (HBSS) buffer, incubated with ginsenoside $\mathrm{Rb} 1$ or medium for $1 \mathrm{~h}$ at $37^{\circ} \mathrm{C}$ and then stimulated with $10 \mathrm{ng} / \mathrm{ml}$ DNP-BSA plus $30 \mu \mathrm{M}$ substance $\mathrm{P}$ for $30 \mathrm{~min}$ at $37^{\circ} \mathrm{C}$. Histamine content in the supernatant and in the cells was measured by the $o$-phthalaldehyde fluorometric according to the procedure described by Yoshimura et al. [18]. Histamine release (\%) was expressed as the percentage of total histamine content.

IL-4 and LTC $_{4}$ content in culture supernatants were determined by ELISA kits (R\&D, Minneapolis, MN and Cayman chemical, Ann Arbor, MI, USA; respectively). The absorbance at $410 \mathrm{~nm}$ was determined using a microplate reader (spectraMAX 340, Molecular Devices, Sunnyvale, CA, USA).

\section{Western blot analysis}

Cells were washed and protein extracted by using M-PER reagent (Rockford, IL, USA). Lysates were clarified by centrifugation at $12,000 \times g$ for 15 min at $4{ }^{\circ} \mathrm{C}$. The protein content was determined with the aid of Bio-Rad DC Protein Assay Kit. Equal amounts of samples were subjected to SDS-PAGE using 10\% running-gels. Proteins were transferred into PVDF membrane and blocking with $5 \%$ non-fat milk $2 \mathrm{~h}$ at room temperature. To study the mitogen-activated protein kinases (MAPKs) signaling pathway, the membranes were then incubated overnight at $4{ }^{\circ} \mathrm{C}$ with anti-phospho-p38, ERK, JNK, or $\beta$-actin antibodies. Membranes were then incubated for $2 \mathrm{~h}$ with the appropriate horseradish peroxidaseconjugated anti-IgG. Proteins were detected by the ECL system (Amersham, Berkshire, UK) and quantified by densitometric analysis (Digital Image Analysis System, PDI, Huntington Station, NY, USA). 


\section{Statistical analysis}

Results are expressed as mean \pm standard error of the means from at least three experiments. Comparisons among several groups were performed with non-parametric ANOVA. Comparisons between two groups were performed with the student's $t$-test. A value of $p<0.05$ was considered statistically significant.

\section{Results}

\section{Effect of SP on allergen-induced mediators}

RBL-2H3 cells have been used for the study of IgE-mediated degranulation, secretion of inflammatory mediators, such as histamine, $\mathrm{LTC}_{4}$ release and IL-4 [19]. Our results were consistent with the previous reports on DNP-induced mediator release. The DNP-BSA dose-dependently affected histamine, $\mathrm{LTC}_{4}$ and IL-4 release from RBL cells with a sub-optimal concentration of $10 \mathrm{ng} / \mathrm{ml} \mathrm{IgE}$. (data not shown). SP $(0.001-30 \mu \mathrm{M})$ alone did not induce histamine and $\mathrm{LTC}_{4}$ release, but it enhanced allergen-induced histamine and $\mathrm{LTC}_{4}$ release from RBL-2H3 cells. However, SP significantly induced IL-4 alone and with allergen (Figure 1).

\section{Effect of Rb1 on SP-enhanced mediator production}

To investigate whether ginsenoside $\mathrm{Rb} 1$ has antiallergic activity, we used SP-enhancement of IgE/ DNP-activated RBL-2H3 cells for the study. We found that $\mathrm{Rb} 1$ dose-dependently $(50-100 \mu \mathrm{M})$ inhibited histamine and $\mathrm{LTC}_{4}$ release far below the levels induced by IgE/DNP-BSA. In addition, Rb1 dose-dependently $(20-100 \mu \mathrm{M})$ inhibited SPenhanced IL-4 secretion (Figure 2).

\section{MAPK activation in $\mathrm{RBL}-2 \mathrm{H} 3$ cells}

SP alone or IgE/DNP induced MAPK activation in RBL-2H3 cells. SP dose-dependently enhanced the $\operatorname{IgE} / \mathrm{DNP}$-activated ERK pathway more prominently than $\mathrm{p} 38$ or JNK MAPKs (Figure 3). U0126 specifically inhibited SP enhancement of allergen-activated ERK and Rb1 dose-dependently $(20-100 \mu \mathrm{M})$ inhibited the activated ERK $1 / 2$ pathway (Figure 4). Among MAPK inhibitors (from 0.01 to $1 \mu \mathrm{M}$ of concentrations),
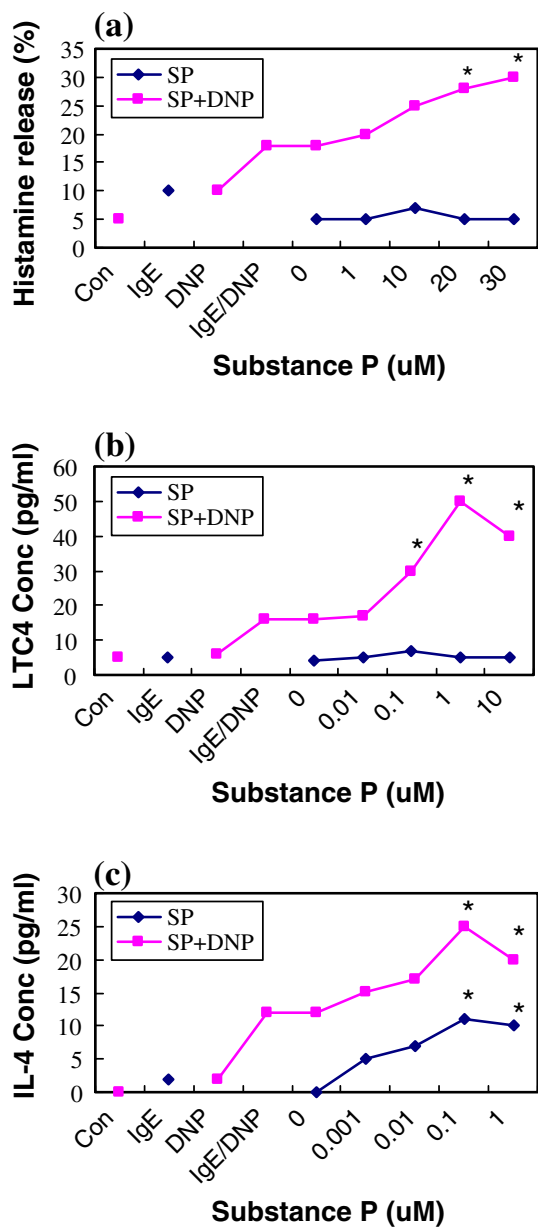

Figure 1. Effects of SP on the allergen-induced mediators from RBL-2H3 cells. SP enhanced DNP-BSA (10 ng/ml)induced histamine (a), $\mathrm{LTC}_{4}(\mathrm{~b})$, and IL-4 (c) release from RBL-2H3 cells $\left(2 \times 10^{5}\right)$ with a sub-optimal concentration of $10 \mathrm{ng} / \mathrm{ml} \mathrm{IgE}$. Histamine release was assayed by a fluorometric method, IL- 4 and LTC $_{4}$ by ELISA kits. Values represent means from five separate experiments. ${ }^{*} p<0.01$ as compared with the IgE/DNP group (mean \pm SEM): histamine release $(20 \pm 2 \%) ; \mathrm{LTC}_{4}(15 \pm 5 \mu \mathrm{g} / \mathrm{ml})$, and IL-4 $(12 \pm 2 \mu \mathrm{g} / \mathrm{ml})$. SP $(\mu \mathrm{M})$ : concentration in $\mu \mathrm{M}$.

U0126 inhibited SP enhanced IgE/DNP-activated histamine release whereas SB203580 or SP600125 did not (Figure 5a). In contrast, all three inhibitors inhibited SP-enhanced allergen-activated $\mathrm{LTC}_{4}$ and IL-4 in RBL-2H3 cells (Figure 5b, c).

\section{Discussion}

Symptoms of asthma/allergic rhinitis are induced by inflammatory mediators, which are released upon activation of mast cells by allergen- $\operatorname{IgE}$ 

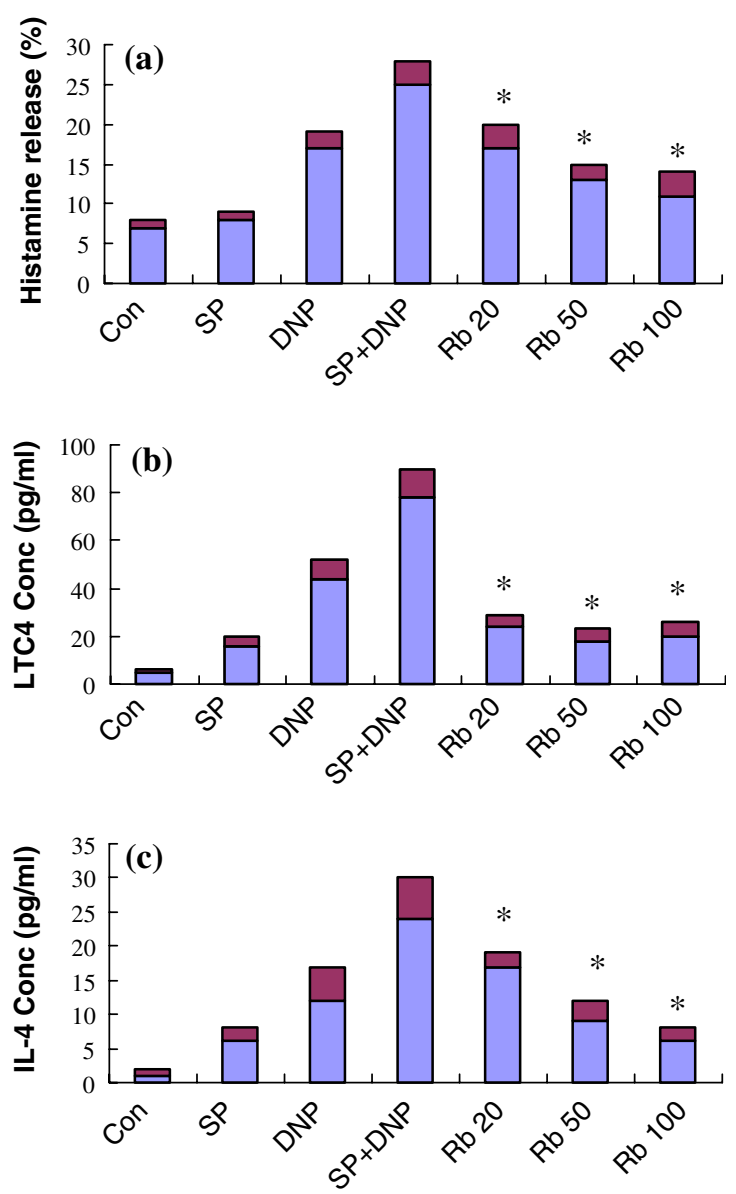

Figure 2. Effects of ginsenoside $\mathrm{Rb} 1$ on the SP enhancement of allergen-induced mediators. Pretreatment $(1 \mathrm{~h})$ with $\mathrm{Rb} 1$ inhibited histamine (a), $\mathrm{LTC}_{4}$ (b), and IL-4 (c) release from the SP enhancement of allergen-induced RBL-2H3 cells. Data represent means \pm SEM from five separate experiments. ${ }^{*} p<0.01$ as compared with the $\mathrm{SP} /$ allergen group. $\mathrm{Rb} 1$ concentrations in $\mu \mathrm{M}: \mathrm{Rb} 20: 20 \mu \mathrm{M}$; Rb 50: $50 \mu \mathrm{M}$; Rb100: $100 \mu \mathrm{M}$.

interaction. These mediators target the end organs directly or indirectly. For instance, stimulation of sensory nerves by histamine may lead to sneezing, pruritus, rhinorrhea, nasal congestion, and asthma. These symptoms are characterized by the phenomenon of hyperresponsiveness to nonallergic stimuli, such as cold air and various irritants and these symptoms may also cause by allergic inflammation on the sensory nerves that supply the upper airway [20, 21]. Therefore, neurogenic inflammation involved airway and other organs, is orchestrated by a large number of neuropeptides including SP and neurokinin A [22]. Allergic inflammation in turns, can induce SP synthesis in large-diameter (A-fiber) ganglion

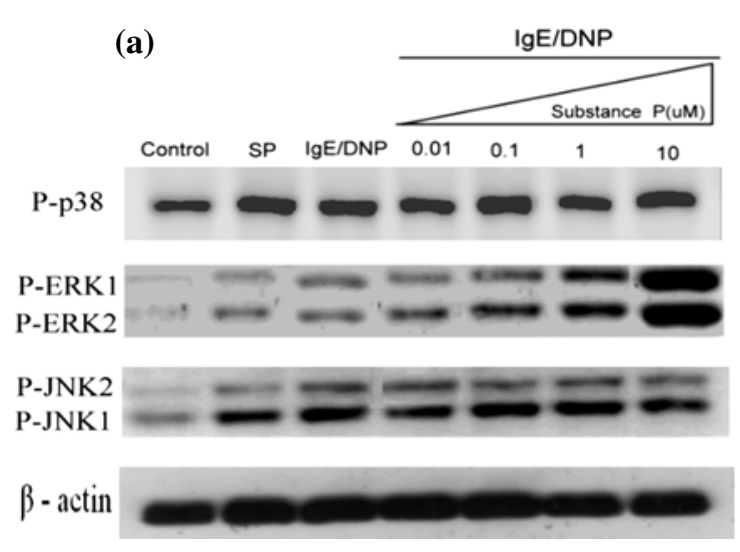

(b)

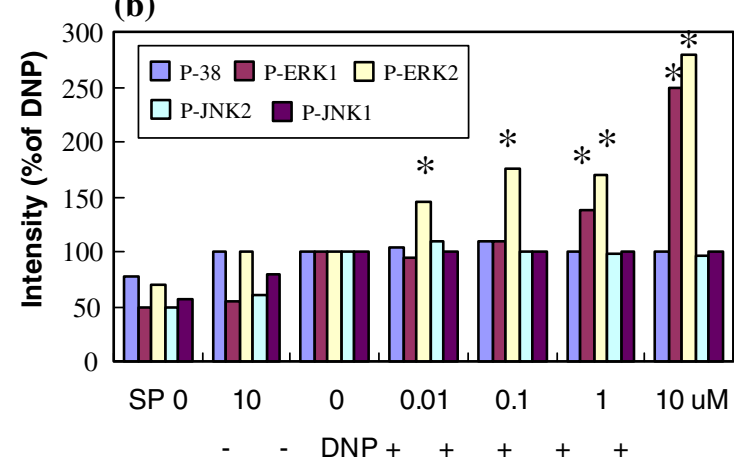

Figure 3. Effect of SP on enhancement of allergen-induced MAPK pathway. RBL-2H3 cells were stimulated with $10 \mathrm{ng} / \mathrm{ml} \mathrm{IgE/DNP-BSA}$ and substance $\mathrm{P}$ for $20 \mathrm{~min}$ at $37^{\circ} \mathrm{C}$ and then were extracted and subjected to Western blotting as described in the Materials and methods. The blotted membranes were examined with anti-phospho-p38, ERK1/2, JNK, or $\beta$-actin antibodies. Upper panel (a): representive blot results. Lower panel (b): densitometry data represented the means from three experiments. ${ }^{*} p<0.05$ as compared with the IgE/DNP group.

neurons innervating guinea pig lungs [23]. Although a recent study showed that SP induced histamine release in human skin mast cells [24], present result agreed with other studies that SP alone did not induce histamine release but enhanced allergen-effect in RBL cells $[5,25]$. The difference may be related to the allergic state of the cells sources.

$\mathrm{SP}$ induces $\mathrm{LTC}_{4}$ release from murine mast cells [26], but RBL-2H3 cells in our study did not. The discrepancy may be due to the different sources of the mast cells, similar to the controversy of histamine release $[24,25]$. However, we found that SP significantly enhanced allergen-induced $\mathrm{LTC}_{4}$ release. $\mathrm{LTC}_{4}$ and its metabolites are extremely potent bronchoconstrition agents that 

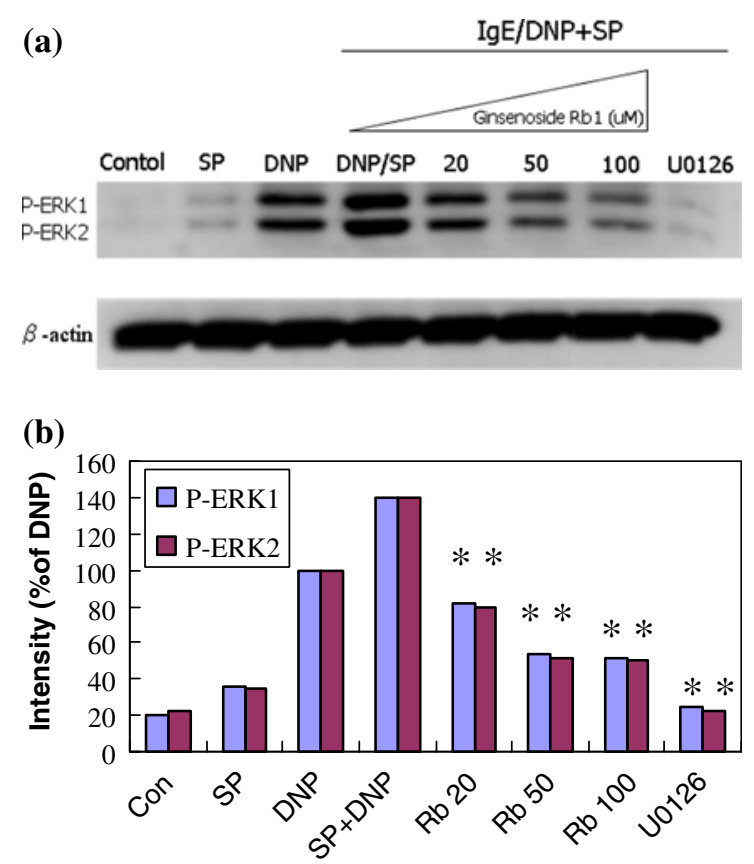

Figure 4. Effect of Rb1 on SP enhancement of IgE/DNPinduced MAPK activation. RBL-2H3 cells were pretreated with $\mathrm{Rb} 1$ for $1 \mathrm{~h}$ and subjected to Western blotting analysis for MAPK phosphorylation. Upper panel (a): representive blot results showed that $\mathrm{Rb} 1(20-100 \mu \mathrm{M})$ and $\mathrm{U} 0126(1 \mu \mathrm{M})$ specifically inhibited the SP enhancement of allergen-activated ERK1/2. Lower panel (b): densitometry data represented the means from three experiments. ${ }^{*} p<0.05$ as compared with the $\mathrm{SP} /$ allergen group.

are pathogenic in both asthma and allergy [10-12]. In addition, SP alone induced IL-4 similar to the other report [27] and it enhanced allergen-induced IL-4 from RBL-2H3 cells. Mast cell activation provides a rapid and local pulse of IL-4 into the local environment essential for the triggering of $\mathrm{T}$ lymphocytes into sustained IL-4 production [28, 29]. Human mast cells storing IL-4 within the granules are likely to have an important influence during the initiation and maintenance of the allergic response [30]. In corroborate with this, a recent study with combined analyses of genetic alterations in the IL-4/IL-13 pathway reveals its actual significance to the development of atopy and childhood asthma [31].

Ginseng has long been used for enhancing brain function, immunity and anti-inflammation. Ginsenoside $\mathrm{Rb} 1$ potentiates the effects of nerve growth factor on nerve fiber outgrowth [32] and increases choline uptake by the brain [33]. Previously, pretreatment of $\mathrm{Rb} 1(91 \mu \mathrm{M})$ had been
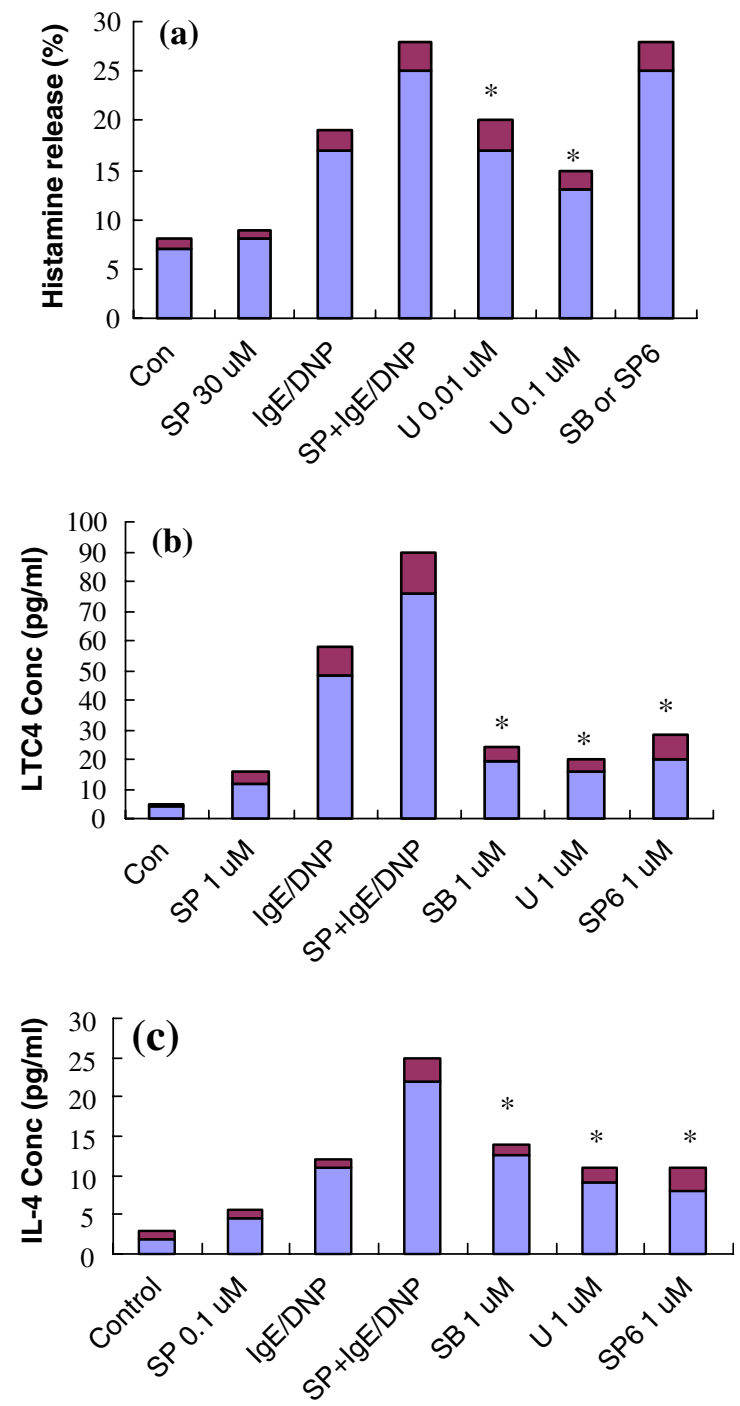

Figure 5. Effects of MAPK inhibitors on SP enhancement of allergen-induced mediators from RBL-2H3 cells. Cells were pretreated with U0126 (U), SB203580 (SB) and SP600125 (SP6) for $1 \mathrm{~h}$ and then assayed the mediators from SP enhanced IgE/DNP-activated cells. Suppression of histamine (a), $\mathrm{LTC}_{4}$ (b) and IL-4 (c) release by inhibitors of MAPKs are compared with each $\mathrm{SP} /$ allergen group. Data represent means \pm SEM from three experiments. ${ }^{*} p<0.05$ as compared with the $\mathrm{SP} /$ allergen group.

shown to decrease histamine and LT in allergenactivated lung mast cells [17]. Just as expected, we observed that $\mathrm{Rb} 1 \quad(20-100 \mu \mathrm{M})$ significantly inhibited histamine, IL-4, and $\mathrm{LTC}_{4}$ release from SP-enhanced allergen-activated RBL-2H3 cells. Thus, the suppression of Rb1 on SP-enhanced inflammatory mediators may provide a new approach for treating neurogenic inflammation. 
SP stimulated TNF- $\alpha$ production in rat peritoneal mast cells is involved with MAPKs signaling pathways [33]. We found that SP or allergen induced ERK, JNK and p38 MAP kinase pathways in RBL-2H3 cells and SP enhanced allergeninduced ERK $1 / 2$ more prominently than other MAP kinases. Our result shows that Rb1 dosedependently inhibited the activated ERK $1 / 2$ pathway. Furthermore, all three inhibitors of MAP kinases suppressed $\mathrm{LTC}_{4}$ and IL-4 from SPenhanced RBL-2H3 cells. However, U0126 selectively suppressed histamine release from the SP enhanced cells. This suggests that the ERK signaling pathway is more important to RBL-2H3 cells under SP and/or allergen activation. A previous study showed that U0126 slightly reduced OVA-induced release of histamine but significantly inhibited the release of LTs from guinea pig lung fragments [34]. In contrast, a study with rat peritoneal mast cells showed that p38 MAPK and JNK, but not ERK, were induced 5 min after exposure to SP and the specific p38 MAPK inhibitor SB203580 abolished SP-induced increase in TNF- $\alpha$ and reduced histamine secretion [35]. Exposure of human basophils to allergens results in a rapid secretion of mediators such as histamine, LTC $_{4}$, IL-4 and IL-13 which involves PI 3-kinase and the subsequent activation of p38 MAPK and ERK1/2 but not JNK [36]. These differences in the activation of MAPK pathway are possibly due to different responses in cell types. Nevertheless, these MAPK-activated mediators are targets of current asthmatic therapy consisting of anti-histamines, LT antagonists, anti-inflammatory glucocorticoid, and humanized monoclonal antibodies against IgE and IL-4 [37].

In summary, neurogenic factor such as SP plays a role in enhancing the allergen-activation of mast cells. Rb1 may exert their effects by stabilizing nerves from secreting neuropeptides and reducing neurogenic inflammation. Therefore, the inhibitory effects of Rb1 on neurogenic inflammation may provide an additional therapeutic strategy for asthma.

\section{Acknowledgements}

This study was supported by NSC932320B0 75004 and 942320B075A002 grants from the National Science Council of ROC.

\section{References}

1. Kraneveld A.D. and Nijkamp F.P., Tachykinins and neuro-immune interactions in asthma. Int. Immunopharmacol. 1: 1629-1650, 2001.

2. Groneberg D.A., Quarcoo D., Frossard N. and Fischer A., Neurogenic mechanisms in bronchial inflammatory diseases. Allergy 59: 1139-1152, 2004.

3. Dinh Q.T., Groneberg D.A., Peiser C., Mingomataj E., Joachim R.A., Witt C., Arck P.C., Klapp B.F. and Fischer A., Substance P expression in TRPV1 and trkA-positive dorsal root ganglion neurons innervating the mouse lung. Respir. Physiol. Neurobiol. 144: 15-24, 2004.

4. Heaney L.G., Cross L.J., Stanford C.F. and Ennis M., Substance $\mathrm{P}$ induces histamine release from human pulmonary mast cells. Clin. Exp. Allergy 25: 179-186, 1995.

5. Lau A.H., Chow S.S. and Ng Y.S., Immunologically induced histamine release from rat peritoneal mast cells is enhanced by low levels of substance P. Eur. J. Pharmacol. 414: 295-303, 2001.

6. Maghni K., Taha R., Afif W., Hamid Q. and Martin J.G., Dichotomy between neurokinin receptor actions in modulating allergic airway responses in an animal model of helper $\mathrm{T}$ cell type 2 cytokine-associated inflammation. Am. J. Respir. Crit. Care Med. 162: 1068-1074, 2000.

7. Maezawa Y., Nakajima H., Kumano K., Kubo S., Karasuyama H. and Iwamoto I., Role of $\operatorname{IgE}$ in Th2 cellmediated allergic airway inflammation. Int. Arch. Allergy Immunol. 131(Suppl 1) 2-6, 2003.

8. Khodoun M.V., Orekhova T., Potter C., Morris S. and Finkelman F.D., Basophils initiate IL-4 production during a memory T-dependent response. J. Exp. Med. 200: 857870, 2004.

9. Nayak A., A review of montelukast in the treatment of asthma and allergic rhinitis. Expert Opin. Pharmacother. 5: 679-686, 2004.

10. Mechiche H., Naline E., Candenas L., Pinto F.M., Birembault P., Advenier C. and Devillier P., Effects of cysteinyl leukotrienes in small human bronchus and antagonist activity of montelukast and its metabolites. Clin. Exp. Allergy 33: 887-894, 2003.

11. Cai Y., Bjermer L. and Halstensen T.S., Bronchial mast cells are the dominating LTC4S-expressing cells in aspirin-tolerant asthma. Am. J. Respir. Cell Mol. Biol. 29: 683-693, 2003.

12. Leff A.R., Regulation of leukotrienes in the management of asthma: biology and clinical therapy. Annu. Rev. Med. 52: $1-14,2001$

13. Andoh T., Katsube N., Maruyama M. and Kuraishi Y., Involvement of leukotriene $\mathrm{B}_{4}$ in substance $\mathrm{P}$-induced itchassociated response in mice. J. Invest. Dermatol. 117: 16211626, 2001.

14. Radad K., Gille G., Moldzio R., Saito H. and Rausch W.D., Ginsenosides Rb1 and Rg1 effects on mesencephalic dopaminergic cells stressed with glutamate. Brain Res. 1021: 41-53, 2004.

15. Park E.K., Choo M.K., Kim E.J., Han M.J. and Kim D.H., Antiallergic activity of ginsenoside Rh2. Biol. Pharm. Bull. 26: 1581-1584, 2003.

16. Park E.K., Shin Y.W., Lee H.U., Kim S.S., Lee Y.C., Lee B.Y. and Kim D.H., Inhibitory effect of ginsenoside Rb1 and compound $\mathrm{K}$ on $\mathrm{NO}$ and prostaglandin $\mathrm{E} 2$ biosyntheses of RAW264.7 cells induced by lipopolysaccharide. Biol. Pharm. Bull. 28: 652-656, 2005. 
17. Ro J.Y., Ahn Y.S. and Kim K.H., Inhibitory effect of ginsenoside on the mediator release in the guinea pig lung mast cells activated by specific antigen-antibody reactions. Int. J. Immunopharmacol. 20: 625-641, 1998.

18. Yoshimura T., Kaneuchi T., Miura T. and Kimura M., Kinetic analysis of the fluorescence reaction of histamine with orthophthalaldehyde. Anal. Biochem. 164: 132-137, 1987.

19. Iwaki S., Ogasawara M., Kurita R., Niwa O., Tanizawa K., Ohashi Y. and Maeyama K., Real-time monitoring of histamine released from rat basophilic leukemia (RBL$2 \mathrm{H} 3$ ) cells with a histamine microsensor using recombinant histamine oxidase. Anal. Biochem. 304: 236-243, 2002.

20. Togias A., Unique mechanistic features of allergic rhinitis. J. Allergy Clin. Immunol. 105: S599-604, 2000.

21. Kudlacz E.M., Combined tachykinin receptor antagonists for the treatment of respiratory diseases. Expert Opin. Investig. Drugs 7: 1055-1062, 1998.

22. O'Connor T.M., O'Connell J., O'Brien D.I., Goode T., Bredin C.P. and Shanahan F., The role of substance P in inflammatory disease. J. Cell Physiol. 201: 167-180, 2004.

23. Chuaychoo B., Hunter D.D., Myers A.C., Kollarik M. and Undem B.J., Allergen-induced substance $\mathrm{P}$ synthesis in large-diameter sensory neurons innervating the lungs. J. Allergy Clin. Immunol. 116: 325-331, 2005.

24. Guhl S., Lee H.H., Babina M., Henz B.M. and Zuberbier T., Evidence for a restricted rather than generalized stimulatory response of skin-derived human mast cells to substance P. J. Neuroimmunol. 163: 92-101, 2005.

25. Bischoff S.C., Schwengberg S., Lorentz A., Manns M.P., Bektas H., Sann H., Levi-Schaffer F., Shanahan F. and Schemann M., Substance P and other neuropeptides do not induce mediator release in isolated human intestinal mast cells. Neurogastroenterol. Motil. 16: 185-193, 2004.

26. Karimi K., Kool M., Nijkamp F.P. and Redegeld F.A., Substance $\mathrm{P}$ can stimulate prostaglandin D2 and leukotriene $\mathrm{C} 4$ generation without granule exocytosis in murine mast cells. Eur. J. Pharmacol. 489: 49-54, 2004

27. Azzolina A., Bongiovanni A. and Lampiasi N., Substance $\mathrm{P}$ induces TNF-alpha and IL-6 production through NF kappa B in peritoneal mast cells. Biochim. Biophys. Acta 1643: 75-83, 2003.
28. Bradding P., Feather I.H., Howarth P.H., Mueller R. Roberts J.A., Britten K., Bews J.P., Hunt T.C., Okayama Y. and Heusser C.H., Interleukin 4 is localized to and released by human mast cells. J. Exp. Med. 1176: 1381-1386, 1992.

29. Bradding P., Roberts J.A., Britten K.M., Montefort S., Djukanovic R., Mueller R., Heusser C.H., Howarth P.H. and Holgate S.T., Interleukin-4, -5 , and -6 and tumor necrosis factor-alpha in normal and asthmatic airways: evidence for the human mast cell as a source of these cytokines. Am. J. Respir. Cell Mol. Biol. 10: 471-480, 1994.

30. Wilson S.J., Shute J.K., Holgate S.T., Howarth P.H. and Bradding P., Localization of interleukin (IL)-4 but not IL-5 to human mast cell secretory granules by immunoelectron microscopy. Clin. Exp. Allergy 30: 493-500, 2000.

31. Kabesch M., Schedel M., Carr D., Woitsch B., Fritzsch C., Weiland S.K. and von Mutius E., IL-4/IL-13 pathway genetics strongly influence serum IgE levels and childhood asthma. J. Allergy Clin. Imm. 117: 269-274, 2006.

32. Saito H., Suda K., Schwab M. and Thoenen H., Potentiation of the NGF-mediated nerve fiber outgrowth by ginsenoside $\mathrm{Rb} 1$ in organ cultures of chicken dorsal root ganglia. Jpn. J. Pharmacol. 27: 445-451, 1997.

33. Benishin C.G., Actions of ginsenoside Rb1 on choline uptake in central cholinergic nerve endings. Neurochem. Int. 21: 1-5, 1992.

34. Chue S.C., Seow C.J., Duan W., Yeo K.S., Koh A.H. and Wong W.S., Inhibitor of p $42 / 44$ mitogen-activated protein kinase, but not p38 MAPK, attenuated antigen challenge of guinea pig airways in vitro. Int. Immunopharmacol. 4: 1089-1098, 2004.

35. Azzolina A., Guarneri P. and Lampiasi N., Involvement of p38 and JNK MAPKs pathways in Substance P-induced production of TNF- $\alpha$ by peritoneal mast cells. Cytokine 18 : 72-80, 2002.

36. Gibbs B.F., Wolff H.H., Zillikens D. and Grabbe J., Differential role for mitogen-activated protein kinases in IgE-dependent signaling in human peripheral blood basophils: in contrast to p38 MAPK, c-Jun N-terminal kinase is poorly expressed and does not appear to control mediator release. Int. Arch. Allergy Immunol. 136: 329339, 2005.

37. Walsh G.M., Novel therapies for asthma- advances and problems. Curr. Pharm. Des. 11: 3027-3038, 2005. 